\title{
Comparison of pediatric scoring systems for mortality in septic patients and the impact of missing information on their predictive power: a retrospective analysis
}

\author{
Christian Niederwanger ${ }^{1}$, Thomas Varga ${ }^{2}$, Tobias Hell ${ }^{3}$, Daniel Stuerzel ${ }^{4}$, Jennifer Prem ${ }^{4}$, Magdalena Gassner ${ }^{4}$, \\ Franziska Rickmann ${ }^{4}$, Christina Schoner ${ }^{4}$, Daniela Hainz ${ }^{4}$, Gerhard Cortina ${ }^{1}$, Benjamin Hetzer ${ }^{1}$, Benedikt Treml ${ }^{4}$ \\ , Mirjam Bachler ${ }^{\text {Corresp. 4, } 5}$ \\ 1 Department of Pediatrics, Pediatrics I, Medical University of Innsbruck, Innsbruck, Austria \\ 2 Institute of Anaesthesiology, University of Zurich and University Hospital Zurich, Zurich, Switzerland \\ 3 Department of Mathematics, Faculty of Mathematics, Computer Science and Physics, University of Innsbruck, Innsbruck, Austria \\ 4 Department of General and Surgical Critical Care Medicine, Medical University of Innsbruck, Innsbruck, Austria \\ 5 Department of Sports Medicine, Alpine Medicine and Health Tourism, UMIT - University for Health Sciences, Medical Informatics and Technology, Hall in \\ Tyrol, Austria \\ Corresponding Author: Mirjam Bachler \\ Email address: mirjam.bachler@tirol-kliniken.at
}

Background: Scores can assess the severity and course of disease and predict outcome in an objective manner. This information is needed for proper risk assessment and stratification. Furthermore, scoring systems support optimal patient care, resource management and are gaining in importance in terms of artificial intelligence.

Objective: This study evaluated and compared the prognostic ability of various common pediatric scoring systems (PRISM, PRISM III, PRISM IV, PIM, PIM2, PIM3, PELOD, PELOD 2) in order to determine which is the most applicable score for pediatric sepsis patients in terms of timing of disease survey and insensitivity to missing data.

Methods: We retrospectively examined data from 398 patients under 18 years of age, who were diagnosed with sepsis. Scores were assessed at ICU admission and re-evaluated on the day of peak Creactive protein. The scores were compared for their ability to predict mortality in this specific patient population and for their impairment due to missing data.

Results: PIM (AUC $0.76(0.68-0.76)$ ), PIM2 (AUC 0.78 (0.72-0.78)) and PIM3 (AUC 0.76 (0.68-0.76)) scores together with PRSIM III (AUC $0.75(0.68-0.75)$ ) and PELOD 2 (AUC $0.75(0.66-0.75)$ ) are the most suitable scores for determining patient prognosis at ICU admission. Once sepsis is pronounced, PELOD 2 (AUC $0.84(0.77-0.91))$ and PRISM IV (AUC $0.8(0.72-0.88)$ ) become significantly better in their performance and count among the best prognostic scores for use at this time together with PRISM III (AUC 0.81 (0.73-0.89)). PELOD 2 is good for monitoring and, like the PIM scores, is also largely insensitive to missing values.

Conclusion: Overall, PIM scores show comparatively good performance, are stable as far as timing of the disease survey is concerned, and they are also relatively stable in terms of missing parameters. PELOD 2 is best suitable for monitoring clinical course. 


\section{Comparison of Pediatric Scoring Systems for Mortality in Septic}

\section{Patients and the Impact of Missing Information on their Predictive}

5

6

\section{Power: a retrospective analysis}

Christian Niederwanger ${ }^{1}$, Thomas Varga ${ }^{2}$, Tobias Hell ${ }^{3}$, Daniel Stürzel ${ }^{4}$, Jennifer Prem ${ }^{4}$, Magdalena Gasser ${ }^{4}$, Franziska Rickmann ${ }^{4}$, Christina Schoner ${ }^{4}$, Daniela Hainz ${ }^{4}$, Gerard Cortina ${ }^{1}$, Benjamin Hetzer ${ }^{1}$, Benedikt Treml ${ }^{4}$, Mirjam Bachler ${ }^{4,5 *}$

${ }^{1}$ Department of Pediatrics, Pediatrics I, Medical University of Innsbruck, Innsbruck, Austria

${ }^{2}$ Institute of Anaesthesiology, University of Zurich and University Hospital Zurich, Zurich, Switzerland

${ }^{3}$ Department of Mathematics, Faculty of Mathematics, Computer Science and Physics, University of Innsbruck, Austria

${ }^{4}$ Department of General and Surgical Critical Care Medicine, Medical University of Innsbruck, Innsbruck, Austria

${ }^{5}$ Department of Sports Medicine, Alpine Medicine and Health Tourism, UMIT - University for Health Sciences, Medical Informatics and Technology, Hall in Tyrol, Austria

\section{*Correspondence:}

Mirjam Bachler

e-mail: mirjam.bachler@tirol-kliniken.at

Keywords: sepsis, children, critical care, mortality scores, missing data 


\section{ABSTRACT}

Background: Scores can assess the severity and course of disease and predict outcome in an objective manner. This information is needed for proper risk assessment and stratification. Furthermore, scoring systems support optimal patient care, resource management and are gaining in importance in terms of artificial intelligence.

Objective: This study evaluated and compared the prognostic ability of various common pediatric scoring systems (PRISM, PRISM III, PRISM IV, PIM, PIM2, PIM3, PELOD, PELOD 2) in order to determine which is the most applicable score for pediatric sepsis patients in terms of timing of disease survey and insensitivity to missing data.

Methods: We retrospectively examined data from 398 patients under 18 years of age, who were diagnosed with sepsis. Scores were assessed at ICU admission and re-evaluated on the day of peak C-reactive protein. The scores were compared for their ability to predict mortality in this specific patient population and for their impairment due to missing data.

Results: PIM (AUC $0.76(0.68-0.76)$ ), PIM2 (AUC 0.78 (0.72-0.78)) and PIM3 (AUC 0.76 (0.680.76)) scores together with PRSIM III (AUC 0.75 (0.68-0.75)) and PELOD 2 (AUC 0.75 (0.660.75)) are the most suitable scores for determining patient prognosis at ICU admission. Once sepsis is pronounced, PELOD 2 (AUC $0.84(0.77-0.91)$ ) and PRISM IV (AUC 0.8 (0.72-0.88)) become significantly better in their performance and count among the best prognostic scores for use at this

47 time together with PRISM III (AUC 0.81 (0.73-0.89)). PELOD 2 is good for monitoring and, like the PIM scores, is also largely insensitive to missing values. 
49 Conclusion: Overall, PIM scores show comparatively good performance, are stable as far as 50 timing of the disease survey is concerned, and they are also relatively stable in terms of missing 51 parameters. PELOD 2 is best suitable for monitoring clinical course. 
53

54

55

56

57

58

59

60

61

62

63

64

65

66

67

68

69

70

71

72

73

74

\section{INTRODUCTION}

Early detection of critically ill patients is essential for timely, good care in a suitable facility. Sepsis remains one of the leading causes of childhood death, although our understanding of the pathophysiology of sepsis has changed drastically in the last couple of decades due to the development of new diagnostic projections and strategies in the treatment of this complex illness (Dellinger et al. 2013).

To help assess severity of illness for risk stratification in terms of required resources, stratify patients prior to randomization in clinical trials, compare intra- and inter-institutional outcome and survival, improve quality assessment as well as cost-benefit analysis, and to facilitate clinical decision making, prognostic scoring systems were established in the 1980s and have been improved and validated since (Lemeshow \& Le 1994; Marcin et al. 1998).

The first scoring systems were developed for adults and were less suitable for use in children. Finally, corresponding scores were presented specially for children and continuously developed and improved (Leteurtre et al. 1999; Pollack et al. 1988; Shann et al. 1997). Some of them permit the probability of survival to be estimated as a function of the determined score. Today's scores, which are especially suitable for children, are, for example, the Pediatric Risk of Mortality (PRISM) score, from which its further developments, namely the PRISM III and PRISM IV scores, the Pediatric Index of Mortality (PIM) score, were derived, the PIM2 and PIM3 scores and the PELOD (Pediatric Logistic Organ Dysfunction) score followed by the PELOD 2 score (Leteurtre et al. 2006; Leteurtre et al. 2013; Leteurtre et al. 1999; Pollack et al. 2016; Pollack et al. 1996b; Pollack et al. 1988; Shann et al. 1997; Slater et al. 2003; Straney et al. 2013). Only few studies deal with the question whether the individual scores are equally suitable for all types of conditions 
75 (Dewi et al. 2019; Gemke \& van Vught 2002; Leteurtre et al. 2001; Muisyo et al. 2019; Qiu et al. 76 2017b).

77 For each score, the development identified specific times or timescales for patient enrollment, 78 within which the score provides the most accurate indication of the patient's condition and the 79 likelihood of survival (Leteurtre et al. 2006; Leteurtre et al. 2013; Leteurtre et al. 1999; Pollack et 80 al. 2016; Pollack et al. 1996b; Pollack et al. 1988; Shann et al. 1997; Slater et al. 2003; Straney et al. 2013). However, some patients develop certain life-threatening conditions - such as sepsis only during their inpatient stay and are actually hospitalized for a completely different reason, for example following a surgical intervention (Sidhu et al. 2015). In such a case, it is obvious that the condition of the patient determined at admission can only conditionally predict the course of a complication developed at a later time. Although some scores consider the admission reason in their evaluation (Pollack et al. 2016; Straney et al. 2013), the further course is still open.

Scores are calculated based on vital signs, laboratory parameters and other patient parameters. In everyday clinical practice and of course as a consequence of the retrospective study design it is often not possible to determine all required data, because they are not recorded, not collected or can no longer be found. However, incomplete data raise the question of score accuracy. Some evidence suggests that knowing the completeness of necessary data is essential for correct score 92 results (Agor et al. 2019; Gorges et al. 2018).

93 This knowledge of data completeness and its impact on the results is becoming of even more 94 interest with regard to the keyword "artificial intelligence." More and more artificial intelligence assessments are based on patient stratification and different kinds of scores (Abbasi 2018;

96 Komorowski et al. 2018). For this reason, it is wise to also know more about the influence of 
97 "missing values" on the accuracy of the informative value of the scores, since not all parameters

98 needed for creation of the scores are available or measured.

99 In this study, the usual pediatric scores are compared in terms of their predictive value in a group 100 of septic children. Also, the optimal timing for determining these scores in the clinical course 101 picture of sepsis was evaluated in addition to the influence of the lack of data on the predictive 102 value of the different scores.

\section{METHODS}

This retrospective analysis included 398 critically ill pediatric patients treated at Innsbruck 106 Medical University Hospital.

\section{Inclusion of patients}

108

109

110

111

112

113

114

115

116

117
The medical files of patients younger than 18 years of age with diagnosed sepsis or a proven blood stream infection between 2000 and 2019 were reviewed. Children fulfilling the definitions according to the International Pediatric Consensus Conference (Goldstein et al. 2005) were included. The current definition of pediatric sepsis is systemic inflammatory response syndrome (SIRS) in the presence of or as a result of suspected or proven infection (Goldstein et al. 2005). SIRS is given when at least two of the four criteria are present, one of which must be abnormal temperature or leukocyte count (Goldstein et al. 2005). In this connection, the fulfillment of SIRS criteria is dependent on the age-specific normal values. The study protocol was approved by the institutional review board of the Medical University of Innsbruck (AN2013-0044 and EK Nr: 1109/2019). 


\section{Data collection}

119 We collected the demographic variables such as age, sex and the diagnosed underlying disease.

120 The underlying disease was assigned to the appropriate organ category: central nervous system,

121 cardiovascular system, respiratory system, hepatic or renal failure. Also recorded was whether the

122 patient suffered from an oncologic disease. Furthermore, we collected routinely measured

123 laboratory parameters on the day of peak C-reactive protein.

124 C-reactive protein was chosen as parameter for the most severe stage of sepsis since it reflects the

125 inflammatory process and is widely used in clinical routine. Many studies have described an

126 interrelation between an elevated C-reactive protein level and sepsis (Koozi et al. 2020; Maury

127 1989; Povoa et al. 1998; Presterl et al. 1997; Schentag et al. 1984) and that C-reactive protein is

128 highest at the most severe point of sepsis (Castelli et al. 2004; Lobo et al. 2003; Povoa et al. 1998;

129 Povoa et al. 2005). Furthermore, elevated C-reactive protein is also associated with organ failure

130 (de Beaux et al. 1996; Ikei et al. 1998; Pinilla et al. 1998; Rau et al. 2000; Waydhas et al. 1996),

131 which makes C-reactive protein a suitable parameter for the surveillance of sepsis severity.

PRISM, PRISM III, PRISMIV, PIM, PIM2, and PIM3 as well as PELOD and PELOD2 scores were retrospectively assessed. Since in the realm of this study the scores were evaluated for their

134 ability to depict the disease process and etiology, we have chosen two time points for score assessment, namely the day of admission as well as the day of peak C-reactive protein

136 (Supplemental File 1). In this way we were able to analyze whether the time of assessment

137 influences the predictive power of the individual scores. In-hospital mortality and multi-organ 138 dysfunction syndrome (MODS) were chosen as outcome parameters. During data acquisition, the 
139 percentage of missing values was recorded for each score as a function of the number of their 140 requested parameters.

\section{Statistical Analysis}

143 A mathematician $(\mathrm{TH})$ not involved in the study procedures or patient assessment was responsible

144 for the statistical analyses conducted using R, version 3.5.3. We present continuous data as median

145 (25th to 75 th percentile) and categorical variables as frequencies (\%). We show effect size and

146 precision with estimated median differences between survivors and non-survivors for continuous

147 data and odds ratios (OR) for binary variables, with 95\% CIs. All statistical assessments were two-

148 sided, and a significance level of 5\% was used. We applied the Wilcoxon rank sum test and Fisher's

149 exact test to assess differences between survivors and non-survivors.

150 The precision of the scores as the difference between predicted mortality and actual mortality is

151 presented depending on the percentage of missing parameters. With respect to their diagnostic

152 ability, the scores were compared by means of ROC curves, and DeLong's test was used to assess

153 differences in ROC AUC. Corresponding 95\% CIs were provided for the ROC AUC of the scores 154 and the differences in the ROC AUC between scores. For this analysis only complete data were 155 used.

156

157 RESULTS

\section{Patient characteristics:}


159 For this analysis 398 patients met the eligibility criteria for study inclusion. In-hospital mortality

160 in these septic children was $13.6 \%(n=54)$. The median age of the children was 29.6 months,

161 whereas $14.6 \%$ of the study population consisted of neonates. There was no difference in survival

162 between males and females (see Table 1).

163 The most affected organ in terms of underlying disease was the respiratory system in $26.8 \%$ of the

164 children followed by diseases of the central nervous system $(22.3 \%)$ and the cardiovascular system

$165(21.6 \%)$. Only the rate of kidney failure was significantly higher in the non-survivors, whereas the

166 proportion of affected central nervous systems and digestive tracts tended to be higher in the non-

167 survivors as well.

168 Evaluation of scores for the predictive ability for mortality

169 As seen in Fig. 1, the best prediction abilities in our study are seen for PIM (0.76; 0.68 to 0.76$)$,

170 PIM2 (AUC 0.78; 0.72 to 0.78 ) and PIM3 (AUC 0.76; 0.68 to 0.76), although there is no

171 significant difference between them and the other tested scores except for PRISM. PRISM shows

172 the poorest mortality prediction of all tested scores and is significantly poorer than PRISMIII

$173(\mathrm{p}=0.0122)$, PIM $(\mathrm{p}=0.0059), \operatorname{PIM} 2(\mathrm{p}=0.0125)$ and PELOD2 $(\mathrm{p}=0.0359)$. Also, the predictive

174 ability of the scores PRISMIV and PELOD is as poor as that of PRISM, although with a slightly

175 higher AUC. The most recent PRISMIV and PIM3 scores show no improvement in mortality

176 prediction. On the contrary, they even show a deterioration in predictive value in our specific septic

177 population as compared to the predecessor scores.

178 No difference was seen in thromboembolic complications or bleeding events between survivors

179 and non-survivors (Table 2). The parameters for organ function with regard to renal or hepatic

180 impairment also show no difference. Furthermore, in this septic population none of the recorded 
181 inflammatory parameters, namely C-reactive protein, procalcitonin, and interleukin-6, 182 differentiate between survivors and non-survivors. Only the coagulation parameters show different 183 values depending on the survival of the septic children. Fibrinogen, antithrombin and platelets

184 were significantly higher in the survivors. As seen in the global coagulation tests, prothrombin 185 time (PT; Quick) and activated thromboplastin time (aPTT), the patients who did not survive were 186 in a hypocoagulable state. This is also reflected in the statistically larger number of bleeding 187 complications seen in the non-survivors.

\section{Admission versus peak C-reactive protein: Does the time of score evaluation matter?}

To address the next question, namely whether the time of scoring makes a difference, two time points were compared: admission and the time when sepsis was most severe according to peak Creactive protein. Except for PELOD, all scores improved towards the peak in C-reactive protein, as seen from their AUCs in Table 3. PRISMIV and PELOD2 even improved significantly and became, together with PRISMIII, the scores with the highest predictive ability, as seen in their

AUC of $0.8,0.84$ and 0.81 , respectively. The worst performance at this time was seen for PRISM followed by PELOD and PIM3.

\section{Missing Values}

197

Due to the nature of a retrospective design and the non-availability of all data for scoring, we checked whether there is an influence on the predictive ability of the different scores. For this purpose, we compared the actually observed mortality and the individual mortality predictions as well as the AUCs depending on the different accepted extent of missing values.

Comparison of predicted versus actual mortality starts with only patients having no missing values for scoring, as seen in Fig. 2. The more missing values are accepted for scoring, the more patients 
203 are included, until $100 \%$ of the total patient population is included for scoring independently of

204 the extent of their missing values.

205 As expected, depending on the size of the analyzed population, the line depicting the difference in

206 mortalities settles only at a certain population size. When only those patients are included who

207 have few missing values the patient number is very small, too small to make a validated statement

208 about the difference in predicted and observed mortality.

209 With the increasing number of missing values allowed, all scores underestimate the actual

210 mortality, except the PELOD score. The fewer missing parameters are accepted, the more similar

211 the predicted and the actual mortality. Exceptions here are the PELOD and the PRISM scores as

212 well as the PIM3 score with a high negative influenceability due to missing parameters, whereby

213 the small number of cases limits the statement. Also, when comparing AUCs the small sample size

214 is limiting, especially in PIM3.

215 The AUC of the scores changes only minimally as a consequence of the number of missing values.

216 Excluded here is PIM3, whose AUC with the completeness of the parameters is lower than the

217 AUCs with missing values.

218 The PRISM score had a difference of 0.1 in the AUCs with the highest AUC of 0.66 at $50 \%$

219 missing values allowed. PRISMIII and PRISMIV had a difference of 0.11 in the AUCs. PRISMIII

220 and PRISMIV had their highest AUCs of 0.84 at $30 \%$ missing values allowed. Also, the PELOD

221 score had a difference of 0.11 in its AUCs, calculated according to the degree of missing values,

222 with the highest AUC of 0.74 at $30 \%-40 \%$ missing values allowed. 
223 PIM and PIM2 had a difference of only 0.05 in their AUCs and had their highest AUC at 30\% -

$22440 \%$ and 20\% missing values allowed. Also, PELOD 2 had a small difference of 0.07 with its

225 highest AUC at 30\% missing values allowed.

\section{DISCUSSION}

228 The aim of this study was to investigate and compare various common mortality risk assessment 229 scoring systems, namely PRISM, PRISM III, PIM, PIM2, PIM3, PELOD and PELOD2 in 230 pediatric sepsis patients. In doing so, we also evaluated different time points for the score 231 assessments, namely PICU admission and the day of C-reactive protein peak. Furthermore, we 232 investigated the influence of missing parameters on the predictive power of the scores.

\section{Comparison of the scores at admission}

234 The mortality rate in our study was at $13.6 \%$ in the midfield of other PICUs in developed countries

235 (Ruth et al. 2014). The difference between the predicted and the actual mortality of the individual 236 scores in our septic patient population is roughly comparable to that of other studies (Arias Lopez 237 et al. 2018; Dewi et al. 2019; Hamshary et al. 2017; Patki et al. 2017; Qiu et al. 2017a; Qureshi et 238 al. 2007; Taori et al. 2010).

239 The PIM scores (PIM1, PIM2, PIM3) underestimate overall mortality as compared to actual 240 mortality, as confirmed by other studies (Patki et al. 2017; Qiu et al. 2017a; Taori et al. 2010). By 241 contrast, the PRISM score, with its mortality prediction, gives quite a good comparison of the

242 actual mortality of the entire population. This has also been confirmed in other studies (Qiu et al. 243 2017a; Taori et al. 2010). While PELOD showed a slight overprediction in mortality in our 
244 population, PELOD 2 showed a significant underprediction of the observed mortality. An even

245 greater discrepancy was found in a study by Gonçalves et al. (Goncalves et al. 2015).

246 Nevertheless, when looking at the ability to predict mortality for the individual patient, the PIM 2

247 score shows the best performance as reflected by highest AUC, closely followed by PIM and PIM3

248 but also by PRISM III and PELOD 2. Other studies also found a slightly higher AUC in PIM2

249 than in PIM (Brady et al. 2006; Slater \& Shann 2004). Even the good performance of PRISM III

250 and PELOD 2 for the individual mortality prediction was also shown by Gonçalves et al. in a

251 general critically ill pediatric population (Goncalves et al. 2015).

252 We found that the PRISM score to be the worst performer (AUC 0.63) in our septic population. In

253 contrast to our findings, a prospective study conducted in pediatric patient populations of specialist

254 multidisciplinary ICUs showed the AUC (0.90) of the PRISM score to be clearly higher than our

255 result (Slater \& Shann 2004). In another study of children with meningococcal sepsis, the PRISM

256 score even outperformed the PIM score (Leteurtre et al. 2001).

257 There are various ongoing discussions as to whether newer versions of the individual scores will

258 improve the predictive value. While a multicenter study in Italy confirmed a significant

259 improvement in PIM 3 compared to PIM 2 (Wolfler et al. 2016), Tyagi et al. (Tyagi et al. 2018)

260 found no relevant improvement between PIM 2 and PIM 3. We were able to determine an increase

261 in the predictive value of the scores along versions, but the last versions (PIM 3 and PRISM IV)

262 brought no further improvement.

\section{Comparison of the scores recorded at the time of the C-reactive protein peaks}

264 The scores are intended for a broad mass, meaning all kinds of diseases and conditions. For each score, a specific point in time or timeframe was determined, for which the best performance is to 
266 be expected. While the PRISM and PRISM III scores are calculated after 24 hours in-hospital, the

267 PIM scores are computed within the first hour after admission. One drawback of a 24-hour

268 assessment is that the patient may already be dead before the score can give a prognosis. In the

269 case of an assessment made in the first hour, however, there is an inaccuracy factor regarding

270 preclinical care. In seriously ill, well-cared-for and stabilized patients, a score may be deceptively

271 low in value. As of version PIM 2, an attempt was made to compensate this with an additional

272 parameter ("main reason for ICU admission").

273 In septic patients there is a similar problem: in some cases sepsis was the reason for admission,

274 while in other cases sepsis developed during the course of hospital stay, possibly in postoperative 275 patients (Sidhu et al. 2015; Wang et al. 2018). In such a case, sepsis cannot be predicted at the time 276 of admission and thus at the time of data collection. A score calculated during the most severe 277 septic phase would therefore show better performance. Thus, our clientele's scores were reassessed 278 at peak C-reactive protein. This analysis revealed that with disease progression PRISM IV and 279 PELOD 2 were becoming significantly more precise in predicting mortality. We conclude that for 280 PRISMIV and PELOD 2 the time when evaluation is performed is important for mortality 281 prediction, while for the other scores the time of evaluation has no significant influence on the 282 predictive ability of these scores. Just as Leteurtre et al., we feel that especially the PELOD 2 score serves well to monitor the progression of disease severity and predict outcome when evaluated 284 regularly during the course of the disease (Leteurtre et al. 2015).

\section{Comparison of scores for missing parameters}

286 Although it is difficult, even in a prospective setting, to collect all the necessary data for creating 287 the scores (Tibby et al. 2002), it is even more difficult with a retrospective study design. Parameters 
288 are not or not fully recorded, not available at the specified time, not collected or lost due to

289 incomplete documentation. However, this reflects the realism of everyday life.

290 This problem has already been addressed by the developers of the PRISM score, who concluded

291 that the missing values are often normal and therefore will hardly influence the score (Pollack et

292 al. 1996a). The same assumption that missing values are normal was partially implemented in the

293 scoring validation studies (Gorges et al. 2018; Leclerc et al. 2017). It was also incorporated into

294 the PIM score, so that it is possible to specify missing data as such and thus there is no change in

295 score points, which makes sense to a certain extent. For example, a lactate level that describes

296 tissue hypoxia may not have been subject to lab testing by the treating physician, because the

297 patient's medical condition was not presumed to be so poor. The situation is similar for other 298 parameters.

299 Nevertheless, this assumption might be misleading: for example, there is only a small blood 300 volume available for laboratory testing, especially in young pediatric patients (Sztefko et al. 2013).

301 This might be supported by a validation study, where PELOD 2 and PRISM III scores show 302 decreased performance when it is assumed that the unavailable data are within normal ranges 303 (Gorges et al. 2018).

304 We were able to show that only in a few cases was it possible to retrospectively collect $100 \%$ of 305 the data for scoring. Here only a small patient population remained, so that the analyses could no 306 longer be performed validly. However, it was seen that patients with a low percentage of missing 307 values have high mortality.

308 With increasing data availability predicted and actual mortality approached each other, similar to 309 what Agor and his team found in their study of the impact of missing scores on adult scores (Agor 
310 et al. 2019). For our patients, the predicted and the actual mortality were quite close, except for

311 the PRISM, PELOD and PIM3 scores, where the difference between the predicted and the actual

312 mortality fluctuated, especially when only few missing values were allowed.

313 The most stable scores in terms of missing values, defined as the maximum deviation from

314 predicted and actual mortality, have been shown to be PRISM III, PIM and PIM 2. Here, it has to

315 be mentioned that, when a high percentage of missing values is allowed, mortality is

316 underestimated by the scores, while with increasing data availability the scores tend to

317 overestimate. The exceptions here are the PELOD score where the results are converse and

318 PELOD 2 score, which consistently slightly overestimates mortality.

319 The AUC of the scores, however, changes only minimally with the number of missing values

320 allowed. The smallest difference in the AUCs depending on the allowed missing values was seen

321 in the PIM and PIM2 scores as well as the PELOD 2 score, which thus proved to be stable as

322 compared to the missing values.

\section{Limitations}

324 The retrospective study design is limited in terms of score performance because some patients did 325 not have all the data needed to calculate the scores. Since this is a single-center study, the number 326 of patients needed for a valid statistical analysis is low overall, especially in the group of patients 327 with $100 \%$ availability of the required data. In our study we assessed only the average effect of the missing values and not the weighting of the individual missing parameters necessary for the score.

329 On the other hand, it was possible for us to draw a realistic scenario of data availability in 330 connection with the score survey in a retrospective study design. 


\section{CONCLUSION}

333 The results demonstrate that at ICU admission all PIM scores together with PRSIM III and PELOD

3342 are the most suitable scores for mortality prognosis, while the PRISM score is the worst. Once

335 the sepsis is pronounced, PELOD 2 and PRISM IV became significantly better in their

336 performance and count among the best prognostic scores for use at this time. Therefore, when

337 calculated at multiple times, the PELOD 2 score is best suited for assessing the prognosis on an

338 ongoing basis.

339 Overall, PIM scores show comparatively good performance, are stable as far as timing of the

340 disease survey is concerned, and they are also relatively stable in terms of missing parameters.

341 PELOD 2 is the best for monitoring and is also relatively stable in relation to missing values.

\section{ACKNOWLEDGMENTS}

344 We thank Dr. Katharina Auer and Dr. Sophie Hofer, who helped with data acquisition, and Dr.

345 Dietmar Fries for his assistance in conducting this project.

\section{ABBREVIATIONS}

348 aPTT: activated thromboplastin time

349 AUC: area under the curve

350 CI: confidence interval

351 ICU: Intensive Care Unit 
352 PELOD: Pediatric Logistic Organ Dysfunction

353 PICU: Pediatric Intensive Care Unit

354 PIM: Pediatric Index of Mortality

355 PRISM: Pediatric Risk of Mortality

356 PT: prothrombin time (Quick)

357 ROC: receiver operating characteristic 
400

401

402

403

404

\section{REFERENCES}

Abbasi J. 2018. Artificial Intelligence Tools for Sepsis and Cancer. Jama 320:2303. 10.1001/jama.2018.19383

Agor J, Ozaltin OY, Ivy JS, Capan M, Arnold R, and Romero S. 2019. The value of missing information in severity of illness score development. J Biomed Inform 97:103255. 10.1016/j.jbi.2019.103255

Arias Lopez MDP, Boada N, Fernandez A, Fernandez AL, Ratto ME, Siaba Serrate A, and Schnitzler E. 2018. Performance of the Pediatric Index of Mortality 3 Score in PICUs in Argentina: A Prospective, National Multicenter Study. Pediatr Crit Care Med 19:e653-e661. 10.1097/pcc.0000000000001741

Brady AR, Harrison D, Black S, Jones S, Rowan K, Pearson G, Ratcliffe J, and Parry GJ. 2006. Assessment and optimization of mortality prediction tools for admissions to pediatric intensive care in the United kingdom. Pediatrics 117:e733-742. 10.1542/peds.2005-1853

Castelli GP, Pognani C, Meisner M, Stuani A, Bellomi D, and Sgarbi L. 2004. Procalcitonin and C-reactive protein during systemic inflammatory response syndrome, sepsis and organ dysfunction. Crit Care 8:R234-242. 10.1186/cc2877

de Beaux AC, Goldie AS, Ross JA, Carter DC, and Fearon KC. 1996. Serum concentrations of inflammatory mediators related to organ failure in patients with acute pancreatitis. Br J Surg 83:349-353.

Dellinger RP, Levy MM, Rhodes A, Annane D, Gerlach H, Opal SM, Sevransky JE, Sprung CL, Douglas IS, Jaeschke R, Osborn TM, Nunnally ME, Townsend SR, Reinhart K, Kleinpell RM, Angus DC, Deutschman CS, Machado FR, Rubenfeld GD, Webb SA, Beale RJ, Vincent JL, and Moreno R. 2013. Surviving sepsis campaign: international guidelines for management of severe sepsis and septic shock: 2012. Crit Care Med 41:580-637. 10.1097/CCM.0b013e31827e83af

Dewi W, Christie CD, Wardhana A, Fadhilah R, and Pardede SO. 2019. Pediatric Logistic Organ Dysfunction-2 (Pelod-2) score as a model for predicting mortality in pediatric burn injury. Ann Burns Fire Disasters 32:135-142.

Gemke RJ, and van Vught J. 2002. Scoring systems in pediatric intensive care: PRISM III versus PIM. Intensive Care Med 28:204-207. 10.1007/s00134-001-1185-2

Goldstein B, Giroir B, and Randolph A. 2005. International pediatric sepsis consensus conference: definitions for sepsis and organ dysfunction in pediatrics. Pediatr Crit Care Med 6:2-8. 10.1097/01.pcc.0000149131.72248.e6

Goncalves JP, Severo M, Rocha C, Jardim J, Mota T, and Ribeiro A. 2015. Performance of PRISM III and PELOD-2 scores in a pediatric intensive care unit. Eur J Pediatr 174:1305-1310. 10.1007/s00431015-2533-5

Gorges M, Peters C, Murthy S, Pi S, and Kissoon N. 2018. External Validation of the "Quick" Pediatric Logistic Organ Dysfunction-2 Score Using a Large North American Cohort of Critically III Children With Suspected Infection. Pediatr Crit Care Med 19:1114-1119. 10.1097/pcc.0000000000001729

Hamshary A, Sherbini SAE, Elgebaly HF, and Amin SA. 2017. Prevalence of multiple organ dysfunction in the pediatric intensive care unit: Pediatric Risk of Mortality III versus Pediatric Logistic Organ Dysfunction scores for mortality prediction. Rev Bras Ter Intensiva 29:206-212. 10.5935/0103507x.20170029

Ikei S, Ogawa M, and Yamaguchi Y. 1998. Blood concentrations of polymorphonuclear leucocyte elastase and interleukin- 6 are indicators for the occurrence of multiple organ failures at the early stage of acute pancreatitis. J Gastroenterol Hepatol 13:1274-1283.

Komorowski M, Celi LA, Badawi O, Gordon AC, and Faisal AA. 2018. The Artificial Intelligence Clinician learns optimal treatment strategies for sepsis in intensive care. Nat Med 24:1716-1720. 10.1038/s41591-018-0213-5 
405

406

407

408

409

410

411

412

413

414

415

416

417

418

419

420

421

422

423

424

425

426

427

428

429

430

431

432

433

434

435

436

437

438

439

440

441

442

443

444

445

446

447

448

449

450

451

452

Koozi $H$, Lengquist $M$, and Frigyesi A. 2020. C-reactive protein as a prognostic factor in intensive care admissions for sepsis: A Swedish multicenter study. J Crit Care 56:73-79.

10.1016/j.jcrc.2019.12.009

Leclerc F, Duhamel A, Deken V, Grandbastien B, and Leteurtre S. 2017. Can the Pediatric Logistic Organ Dysfunction-2 Score on Day 1 Be Used in Clinical Criteria for Sepsis in Children? Pediatr Crit Care Med 18:758-763. 10.1097/pcc.0000000000001182

Lemeshow S, and Le J-R. 1994. Modeling the severity of illness of ICU patients: a systems update. Jama 272:1049-1055.

Leteurtre S, Duhamel A, Deken V, Lacroix J, and Leclerc F. 2015. Daily estimation of the severity of organ dysfunctions in critically ill children by using the PELOD-2 score. Crit Care 19:324.

10.1186/s13054-015-1054-y

Leteurtre S, Duhamel A, Grandbastien B, Lacroix J, and Leclerc F. 2006. Paediatric logistic organ dysfunction (PELOD) score. Lancet 367:897; author reply 900-892. 10.1016/s01406736(06)68371-2

Leteurtre S, Duhamel A, Salleron J, Grandbastien B, Lacroix J, and Leclerc F. 2013. PELOD-2: an update of the PEdiatric logistic organ dysfunction score. Crit Care Med 41:1761-1773. 10.1097/CCM.0b013e31828a2bbd

Leteurtre S, Leclerc F, Martinot A, Cremer R, Fourier C, Sadik A, and Grandbastien B. 2001. Can generic scores (Pediatric Risk of Mortality and Pediatric Index of Mortality) replace specific scores in predicting the outcome of presumed meningococcal septic shock in children? Crit Care Med 29:1239-1246. 10.1097/00003246-200106000-00033

Leteurtre S, Martinot A, Duhamel A, Gauvin F, Grandbastien B, Nam TV, Proulx F, Lacroix J, and Leclerc F. 1999. Development of a pediatric multiple organ dysfunction score: use of two strategies. Med Decis Making 19:399-410. 10.1177/0272989X9901900408

Lobo SM, Lobo FR, Bota DP, Lopes-Ferreira F, Soliman HM, Melot C, and Vincent JL. 2003. C-reactive protein levels correlate with mortality and organ failure in critically ill patients. Chest 123:20432049.

Marcin JP, Pollack MM, Patel KM, and Ruttimann UE. 1998. Decision support issues using a physiology based score. Intensive Care Med 24:1299-1304.

Maury CP. 1989. Monitoring the acute phase response: comparison of tumour necrosis factor (cachectin) and C-reactive protein responses in inflammatory and infectious diseases. $J$ Clin Pathol 42:1078-1082.

Muisyo T, Bernardo EO, Camazine M, Colvin R, Thomas KA, Borgman MA, and Spinella PC. 2019. Mortality prediction in pediatric trauma. J Pediatr Surg 54:1613-1616. 10.1016/j.jpedsurg.2018.08.045

Patki VK, Raina S, and Antin JV. 2017. Comparison of Severity Scoring Systems in a Pediatric Intensive Care Unit in India: A Single-Center Prospective, Observational Cohort Study. J Pediatr Intensive Care 6:98-102. 10.1055/s-0036-1584811

Pinilla JC, Hayes P, Laverty W, Arnold C, and Laxdal V. 1998. The C-reactive protein to prealbumin ratio correlates with the severity of multiple organ dysfunction. Surgery 124:799-805; discussion 805796. 10.1067/msy.1998.91365

Pollack MM, Holubkov R, Funai T, Dean JM, Berger JT, Wessel DL, Meert K, Berg RA, Newth CJ, Harrison RE, Carcillo J, Dalton H, Shanley T, Jenkins TL, Tamburro R, and Network EKSNIoCHaHDCPCCR. 2016. The Pediatric Risk of Mortality Score: Update 2015. Pediatr Crit Care Med 17:2-9. 10.1097/PCC.0000000000000558

Pollack MM, Patel KM, Ruttimann U, and Cuerdon T. 1996a. Frequency of variable measurement in 16 pediatric intensive care units: influence on accuracy and potential for bias in severity of illness assessment. Crit Care Med 24:74-77. 10.1097/00003246-199601000-00013

Peer] reviewing PDF | (2020:03:47169:1:1:NEW 18 Aug 2020) 
453

454

455

456

457

458

459

460

461

462

463

464

465

466

467

468

469

470

471

472

473

474

475

476

477

478

479

480

481

482

483

484

485

486

487

488

489

490

491

492

493

494

495

496

497

498

499

500

Pollack MM, Patel KM, and Ruttimann UE. 1996b. PRISM III: an updated Pediatric Risk of Mortality score. Crit Care Med 24:743-752. 10.1097/00003246-199605000-00004

Pollack MM, Ruttimann UE, and Getson PR. 1988. Pediatric risk of mortality (PRISM) score. Crit Care Med 16:1110-1116. 10.1097/00003246-198811000-00006

Povoa P, Almeida E, Moreira P, Fernandes A, Mealha R, Aragao A, and Sabino H. 1998. C-reactive protein as an indicator of sepsis. Intensive Care Med 24:1052-1056.

Povoa P, Coelho L, Almeida E, Fernandes A, Mealha R, Moreira P, and Sabino H. 2005. C-reactive protein as a marker of infection in critically ill patients. Clin Microbiol Infect 11:101-108. 10.1111/j.14690691.2004.01044.x

Presterl E, Staudinger T, Pettermann M, Lassnigg A, Burgmann H, Winkler S, Frass M, and Graninger W. 1997. Cytokine profile and correlation to the APACHE III and MPM II scores in patients with sepsis. Am J Respir Crit Care Med 156:825-832.

Qiu J, Lu X, Wang K, Zhu Y, Zuo C, and Xiao Z. 2017a. Comparison of the pediatric risk of mortality, pediatric index of mortality, and pediatric index of mortality 2 models in a pediatric intensive care unit in China: A validation study. Medicine (Baltimore) 96:e6431. 10.1097/md.0000000000006431

Qiu J, Lu X, Wang K, Zhu Y, Zuo C, and Xiao Z. 2017b. Comparison of the pediatric risk of mortality, pediatric index of mortality, and pediatric index of mortality 2 models in a pediatric intensive care unit in China: A validation study. Medicine (Baltimore) 96:e6431-e6431. 10.1097/MD.0000000000006431

Qureshi AU, Ali AS, and Ahmad TM. 2007. Comparison of three prognostic scores (PRISM, PELOD and PIM 2) at pediatric intensive care unit under Pakistani circumstances. J Ayub Med Coll Abbottabad 19:49-53.

Rau B, Steinbach G, Baumgart K, Gansauge F, Grunert A, and Beger HG. 2000. Serum amyloid A versus Creactive protein in acute pancreatitis: clinical value of an alternative acute-phase reactant. Crit Care Med 28:736-742.

Ruth A, McCracken CE, Fortenberry JD, Hall M, Simon HK, and Hebbar KB. 2014. Pediatric severe sepsis: current trends and outcomes from the Pediatric Health Information Systems database. Pediatr Crit Care Med 15:828-838. 10.1097/pcc.0000000000000254

Schentag JJ, O'Keeffe D, Marmion M, and Wels PB. 1984. C-reactive protein as an indicator of infection relapse in patients with abdominal sepsis. Arch Surg 119:300-304.

Shann F, Pearson G, Slater A, and Wilkinson K. 1997. Paediatric index of mortality (PIM): a mortality prediction model for children in intensive care. Intensive Care Med 23:201-207. 10.1007/s001340050317

Sidhu N, Joffe AR, Doughty P, Vatanpour S, Dinu I, Alton G, Acton B, and Robertson CM. 2015. Sepsis After Cardiac Surgery Early in Infancy and Adverse 4.5-Year Neurocognitive Outcomes. J Am Heart Assoc 4:e001954. 10.1161/jaha.115.001954

Slater A, and Shann F. 2004. The suitability of the Pediatric Index of Mortality (PIM), PIM2, the Pediatric Risk of Mortality (PRISM), and PRISM III for monitoring the quality of pediatric intensive care in Australia and New Zealand. Pediatr Crit Care Med 5:447-454. 10.1097/01.Pcc.0000138557.31831.65

Slater A, Shann F, and Pearson G. 2003. PIM2: a revised version of the Paediatric Index of Mortality. Intensive Care Med 29:278-285. 10.1007/s00134-002-1601-2

Straney L, Clements A, Parslow RC, Pearson G, Shann F, Alexander J, Slater A, and Network APSGatPICA. 2013. Paediatric index of mortality 3: an updated model for predicting mortality in pediatric intensive care*. Pediatr Crit Care Med 14:673-681. 10.1097/PCC.0b013e31829760cf

Sztefko K, Beba J, Mamica K, and Tomasik P. 2013. Blood loss from laboratory diagnostic tests in children. Clin Chem Lab Med 51:1623-1626. 10.1515/cclm-2012-0672

Peer] reviewing PDF | (2020:03:47169:1:1:NEW 18 Aug 2020) 
501 Taori RN, Lahiri KR, and Tullu MS. 2010. Performance of PRISM (Pediatric Risk of Mortality) score and

502

503

504

505

506

507

508

509

510

511

512

513

514

515

516

517

518

519

520 PIM (Pediatric Index of Mortality) score in a tertiary care pediatric ICU. Indian J Pediatr 77:267271. 10.1007/s12098-010-0031-3

Tibby SM, Taylor D, Festa M, Hanna S, Hatherill M, Jones G, Habibi P, Durward A, and Murdoch IA. 2002. A comparison of three scoring systems for mortality risk among retrieved intensive care patients. Arch Dis Child 87:421-425. 10.1136/adc.87.5.421

Tyagi P, Tullu MS, and Agrawal M. 2018. Comparison of Pediatric Risk of Mortality III, Pediatric Index of Mortality 2, and Pediatric Index of Mortality 3 in Predicting Mortality in a Pediatric Intensive Care Unit. J Pediatr Intensive Care 7:201-206. 10.1055/s-0038-1673671

Wang Y, Gu Y, Huang F, Liu D, Zhang Z, Zhou N, Liang J, Lu C, Yuan D, and Hei Z. 2018. Risk Factors for Sepsis Based on Sepsis-3 Criteria after Orthotopic Liver Transplantation. Mediators Inflamm 2018:8703172. 10.1155/2018/8703172

Waydhas C, Nast-Kolb D, Trupka A, Zettl R, Kick M, Wiesholler J, Schweiberer L, and Jochum M. 1996. Posttraumatic inflammatory response, secondary operations, and late multiple organ failure. $J$ Trauma 40:624-630; discussion 630-621.

Wolfler A, Osello R, Gualino J, Calderini E, Vigna G, Santuz P, Amigoni A, Savron F, Caramelli F, Rossetti E, Cecchetti C, Corbari M, Piastra M, Testa R, Coffaro G, Stancanelli G, Gitto E, Amato R, Prinelli F, and Salvo I. 2016. The Importance of Mortality Risk Assessment: Validation of the Pediatric Index of Mortality 3 Score. Pediatr Crit Care Med 17:251-256. 10.1097/pcc.0000000000000657 
Figure 1

AUC ROC analysis of admission scores.

Receiver operating characteristic (ROC) curves and area under the curve (AUC) for mortality prediction at admission based on the Pediatric Risk of Mortality scores PRISM (A), PRISM III (B), and PRISM IV (C), the Pediatric Index of Mortality scores PIM (D), PIM 2 (E), and PIM 3 (F), as well as the Pediatric Logistic Organ Dysfunction scores PELOD (G), and PELOD 2 (H). The numbers in the brackets indicate the $95 \%$ Cls for the AUC.
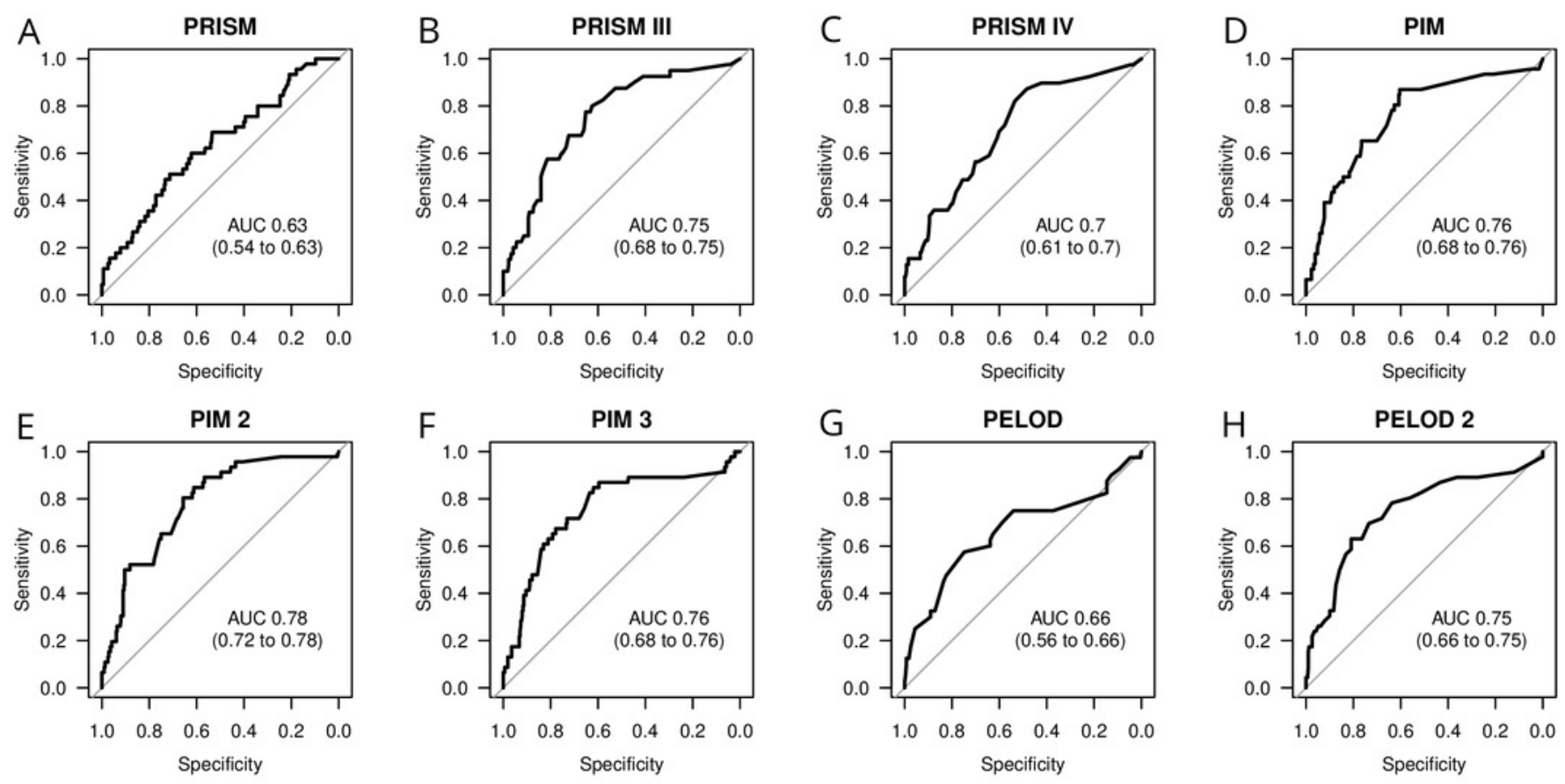


\section{Figure 2}

Influence of missing data on score performance.

Predicted (large dots) and actual (small dots) mortality including the difference ( $\mathrm{x}$ in a circle) depending on the extent of missing values for scoring of the Pediatric Risk of Mortality scores PRISM (A), PRISM III (B), and PRISM IV (C), the Pediatric Index of Mortality scores PIM (D), PIM $2(E)$, and PIM $3(F)$, as well as the Pediatric Logistic Organ Dysfunction scores PELOD (G), and PELOD $2(\mathrm{H})$. The proportion of patients available for analysis from the total population is given in percentage along the $x$ axis in each panel $(A-H)$.
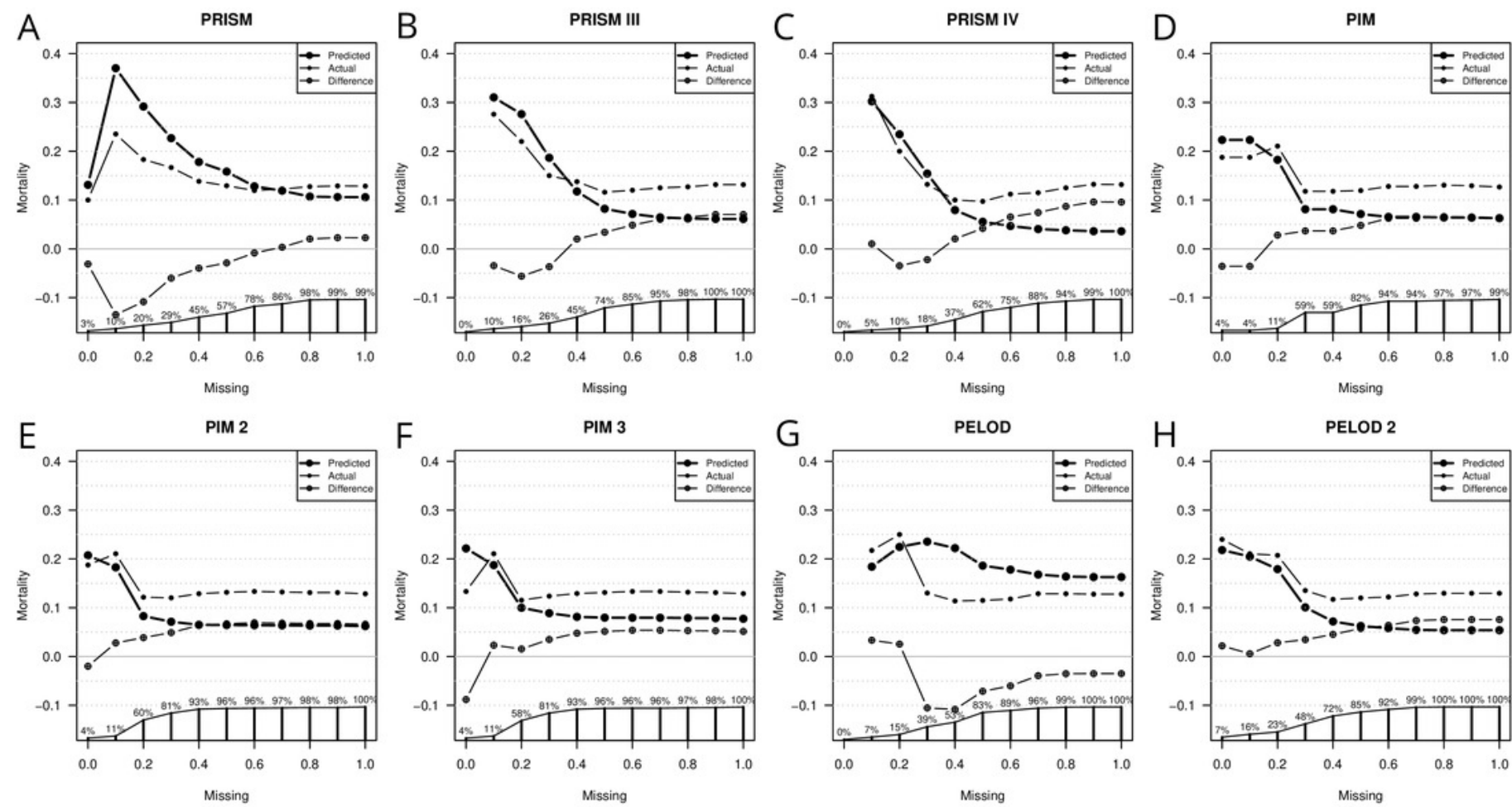


\section{Table 1 (on next page)}

Characteristics $^{\mathrm{a}}$ of patients stratified for survival and non-survival 
1 Table 1. Characteristics ${ }^{a}$ of patients stratified for survival and non-survival

\begin{tabular}{|c|c|c|c|c|c|}
\hline & Total $(n=398)$ & $\begin{array}{l}\text { Non-survivors } \\
\qquad(n=54)\end{array}$ & $\begin{array}{c}\text { Survivors } \\
(\mathrm{n}=\mathbf{3 4 4})\end{array}$ & $\begin{array}{c}\text { Estimate with } 95 \% \\
\text { CI }^{b}\end{array}$ & p value \\
\hline Female gender & $176 / 398(44.2 \%)$ & $22 / 54(40.7 \%)$ & $154 / 344(44.8 \%)$ & $1.18(0.63$ to 2.22$)$ & 0.6591 \\
\hline $\operatorname{Age}^{d}$ (months) & $29.6(3.83-105.64)$ & $22.41(1.22-88.99)$ & $30.68(4.04-107.54)$ & $-1.1(-10.81$ to 5.3$)$ & 0.4817 \\
\hline Neonates $<1$ month & $58 / 396(14.6 \%)$ & $12 / 54(22.2 \%)$ & $46 / 342(13.5 \%)$ & $0.54(0.26$ to 1.22$)$ & 0.0988 \\
\hline Infants $1-3$ months & $35 / 396(8.8 \%)$ & $4 / 54(7.4 \%)$ & $31 / 342(9.1 \%)$ & $1.25(0.41$ to 5.06$)$ & 1 \\
\hline \multicolumn{6}{|c|}{ Predicted mortality (\%) at ICU admission } \\
\hline PRISM & $10.53(1.54-7.55)$ & $19.79(2.3-20.75)$ & $9.17(1.5-7)$ & $10.62(1.3$ to 19.94$)$ & 0.0264 \\
\hline PRISM III & $6.12(0.05-1.73)$ & $17.76(0.39-8.62)$ & $4.36(0.05-1.04)$ & 13.4 (2.92 to 23.87$)$ & 0.0135 \\
\hline PRISM IV & $3.59(0.05-0.71)$ & $12.09(0.12-2.71)$ & $2.31(0.05-0.53)$ & $9.79(0.82$ to 18.76$)$ & 0.0333 \\
\hline PIM & $6.28(1-5)$ & $16.06(2.84-23)$ & $4.83(1-4)$ & $11.23(4.42$ to 18.04$)$ & 0.0017 \\
\hline PIM 2 & $6.23(0.75-4.01)$ & $16.64(2.8-17.1)$ & $4.69(0.75-3.7)$ & 11.95 (4.46 to 19.44$)$ & 0.0024 \\
\hline PIM 3 & $7.72(1.11-4.16)$ & $18.93(2.88-15.3)$ & $6.06(1.11-3.53)$ & $12.86(4.28$ to 21.44$)$ & 0.0041 \\
\hline PELOD & $16.24(0.96-16.25)$ & $32.23(1.2-79.58)$ & $13.9(0.96-16.25)$ & $18.33(6.17$ to 30.5$)$ & 0.004 \\
\hline PELOD 2 & $5.39(0.13-2.21)$ & $18.21(0.87-17.59)$ & $3.48(0.13-1.39)$ & $14.72(5.88$ to 23.56$)$ & 0.0016 \\
\hline \multicolumn{6}{|c|}{ Diagnosed underlying disease } \\
\hline $\begin{array}{l}\text { Central nervous } \\
\text { system }\end{array}$ & $81 / 364(22.3 \%)$ & $15 / 44(34.1 \%)$ & $66 / 320(20.6 \%)$ & $0.5(0.24$ to 1.07$)$ & 0.0532 \\
\hline Cardiovascular & $78 / 361(21.6 \%)$ & $14 / 42(33.3 \%)$ & $64 / 319(20.1 \%)$ & $0.5(0.24$ to 1.1$)$ & 0.0704 \\
\hline Digestive tract & $67 / 364(18.4 \%)$ & $13 / 44(29.5 \%)$ & $54 / 320(16.9 \%)$ & $0.49(0.23$ to 1.08$)$ & 0.0595 \\
\hline $\begin{array}{l}\text { Respiratory } \\
\text { system }\end{array}$ & $97 / 362(26.8 \%)$ & $17 / 43(39.5 \%)$ & $80 / 319(25.1 \%)$ & $0.51(0.25$ to 1.06$)$ & 0.0649 \\
\hline Oncologic & $51 / 365(14 \%)$ & 9/43 (20.9\%) & $42 / 322(13 \%)$ & $0.57(0.24$ to 1.44$)$ & 0.1636 \\
\hline Kidney & $45 / 362(12.4 \%)$ & $10 / 44(22.7 \%)$ & $35 / 318(11 \%)$ & $0.42(0.18$ to 1.04$)$ & 0.0467 \\
\hline Liver & $31 / 363(8.5 \%)$ & $3 / 44(6.8 \%)$ & $28 / 319(8.8 \%)$ & $1.31(0.38$ to 7.05$)$ & 1 \\
\hline Skin & $18 / 361(5 \%)$ & $1 / 43(2.3 \%)$ & $17 / 318(5.3 \%)$ & $2.37(0.35$ to 101.43$)$ & 0.7078 \\
\hline Other diagnoses & $108 / 367(29.4 \%)$ & $16 / 44(36.4 \%)$ & $92 / 323(28.5 \%)$ & $0.7(0.35$ to 1.45$)$ & 0.2931 \\
\hline \multicolumn{6}{|c|}{$\begin{array}{l}\text { a Binary data are presented as no./total no. (\%), continuous data as medians }\left(25^{\text {th }}-75^{\text {th }} \text { percentile), means for predicted mortality }\right. \\
\text { b Odds ratio for binary variables and estimated median difference for continuous variables, mean difference for predicted mortality } \\
\text { c Differences between survivors and non-survivors assessed with Fisher's exact test for binary variables and the Wilcoxon rank sum test for } \\
\text { continuous variables, the Welch two sample T test for predicted mortality } \\
\text { d For one survivor the exact age in months is not known }\end{array}$} \\
\hline
\end{tabular}


Table 2 (on next page)

Outcome parameters ${ }^{\mathrm{a}}$ at peak C-reactive protein stratified for survival and non-survival 
1 Table 2. Outcome parameters ${ }^{a}$ at peak $\mathrm{C}$-reactive protein stratified for survival and non-survival

\begin{tabular}{|c|c|c|c|c|c|c|}
\hline & Total $(n=398)$ & $\begin{array}{l}\text { Non-survivors } \\
\qquad(n=54)\end{array}$ & $\begin{array}{c}\text { Survivors } \\
(\mathrm{n}=344)\end{array}$ & $\begin{array}{c}\text { Estimate with } \\
95 \% \mathrm{CI}^{\mathrm{b}}\end{array}$ & $\underset{\text { value }^{c}}{\mathbf{p}}$ & $\begin{array}{c}\text { Not } \\
\text { known }^{d}\end{array}$ \\
\hline Thromboembolic event & $14 / 398(3.5 \%)$ & $2 / 54(3.7 \%)$ & $12 / 344(3.5 \%)$ & $0.94(0.2$ to 8.89$)$ & 1 & $0 / 0$ \\
\hline Bleeding complication & $20 / 398(5 \%)$ & $9 / 54(16.7 \%)$ & $11 / 344(3.2 \%)$ & $0.17(0.06$ to 0.48$)$ & 0.0004 & $0 / 0$ \\
\hline Creatinine $[\mathrm{mg} / \mathrm{dl}]$ & $0.45(0.3-0.72)$ & $0.58(0.37-0.93)$ & $0.43(0.3-0.71)$ & $0.12(-0.01$ to 0.25$)$ & 0.0645 & $21 / 92$ \\
\hline Bilirubin $[\mathrm{mg} / \mathrm{dl}]$ & $1.05(0.44-4.49)$ & $1.78(0.74-8.01)$ & $1(0.43-4.16)$ & $0.56(-0.07$ to 2$)$ & 0.0761 & $28 / 201$ \\
\hline D-dimer $[\mu \mathrm{g} / \mathrm{l}]$ & $1421(547.5-4595)$ & $1506(310-8037)$ & $\begin{array}{c}1402.5(574- \\
4314.5)\end{array}$ & $\begin{array}{c}-96.59(-589.88 \text { to } \\
728)\end{array}$ & 0.6278 & $17 / 170$ \\
\hline Fibrinogen $[\mathrm{mg} / \mathrm{dl}]$ & $462(314-632)$ & $283.5(186-476.25)$ & $484(337-650)$ & $-165(-237$ to -88$)$ & 0.0001 & $14 / 119$ \\
\hline Antithrombin [\%] & $63(46.5-80.5)$ & $50.5(41.25-64.75)$ & $65(48-82)$ & $-13(-21$ to -4$)$ & 0.0033 & $16 / 147$ \\
\hline $\begin{array}{l}\text { activated partial } \\
\text { thromboplastin time } \\
\text { (aPTT) }[\mathrm{s}]\end{array}$ & $46(37-57.5)$ & $63.5(50.75-76.25)$ & $45(36-54)$ & $18(11$ to 25$)$ & $<0.0001$ & $20 / 123$ \\
\hline $\begin{array}{l}\text { Prothrombin time (PT, } \\
\text { Quick) }[\%]\end{array}$ & $68(50-84)$ & $49(36-71.5)$ & $71.5(55-85)$ & $-19(-27$ to -11$)$ & $<0.0001$ & $19 / 122$ \\
\hline $\begin{array}{l}\text { C-reactive protein } \\
{[\mathrm{mg} / \mathrm{dl}]}\end{array}$ & $15.23(6.44-26.18)$ & $16.83(7.04-33.21)$ & $\begin{array}{c}14.85(6.44- \\
25.15)\end{array}$ & $2.74(-0.86$ to 7.6$)$ & 0.1431 & $2 / 0$ \\
\hline Procalcitonin $[\mathrm{mg} / \mathrm{dl}]$ & $11.3(2.41-40.31)$ & $9.15(4.45-39.48)$ & $11.71(1.9-39.95)$ & $1.26(-6.65$ to 7.63$)$ & 0.6081 & $36 / 221$ \\
\hline Hemoglobin $[\mathrm{g} / 1]$ & $110.5(97-130.75)$ & $113(89-126.5)$ & $110(97-131)$ & $-4(-22$ to 14$)$ & 0.7122 & $43 / 221$ \\
\hline Platelets [G/1] & $145(60-250.5)$ & $53(25-103)$ & $163(81-260)$ & $-86(-119$ to -54$)$ & $<0.0001$ & $1 / 10$ \\
\hline Neutrophils [G/1] & $7.45(3.62-14.05)$ & $9.9(5.27-29.42)$ & $7.1(3.6-13.33)$ & $3.5(-0.3$ to 8.4$)$ & 0.0853 & $34 / 182$ \\
\hline Interleukin 6 [ng/l] & $120.2(34-344.35)$ & $\begin{array}{c}584.85(342.27- \\
827.42)\end{array}$ & $\begin{array}{c}120.2(33.5- \\
276.4)\end{array}$ & $\begin{array}{c}117.22(-358.2 \text { to } \\
1049.3)\end{array}$ & 0.3309 & $52 / 319$ \\
\hline Leukocytes [G/1] & $11.1(5.9-17.85)$ & $8.45(1.87-22.43)$ & $11.4(6.15-17.45)$ & $-1.1(-4.4$ to 1.8$)$ & 0.4045 & $6 / 9$ \\
\hline $\begin{array}{l}\text { Base excess arterial } \\
\text { a Data are presented as me } \\
\text { b Estimated median differe } \\
{ }^{c} \text { Differences between surv } \\
{ }^{d} \text { Number of missing meas }\end{array}$ & $\begin{array}{l}-1(-4.05-1.25) \\
\text { ans }\left(25^{\text {th }}-75^{\text {th }} \text { perc }\right. \\
\text { e }\end{array}$ & $\begin{array}{l}-1(-6.22-2.7) \\
\text { ile) }\end{array}$ & $-1(-3.9-0.9)$ & $-0.2(-3$ to 1.8$)$ & 0.7468 & $28 / 223$ \\
\hline
\end{tabular}




\section{Table 3 (on next page)}

ROC analysis of scores predicting mortality

Results of the score analyses for mortality prediction at hospital admission and on the day with the highest level of C-reactive protein (CRP). The dark grey fields show the AUC with $95 \% \mathrm{Cl}$. The numbers in the fields above the dark grey fields give the estimated difference in ROC curves with $95 \% \mathrm{Cl}$ and the fields below show the correlation with the corresponding ROC curves. Red $\mathrm{p}$ values indicate a significant difference. Only completed cases with all scores available are included. 
2 Results of the score analyses for mortality prediction at hospital admission and on the day with the highest level of C-reactive protein (CRP). The dark grey fields show the AUC with 95\% CI. The numbers in the fields above the dark grey fields give the estimated difference in ROC curves with $95 \% \mathrm{CI}$ and the fields below show the correlation with the corresponding ROC curves. Red $\mathrm{p}$ values indicate a significant difference. Only completed cases with all scores available are 5 included.

\begin{tabular}{|c|c|c|c|c|c|c|c|c|c|c|c|c|c|c|c|c|}
\hline & \multicolumn{8}{|c|}{$\mathrm{p}=0.211$} & \multicolumn{8}{|c|}{$p=0.2778$} \\
\hline & PRISM & I PRISMIII & PRISMIV & PIM & PIM2 & PIM3 & PELOD & PELOD2 & $\begin{array}{c}\text { PRISM } \\
\text { CRP }\end{array}$ & $\begin{array}{l}\text { PRISMIII } \\
\text { CRP }\end{array}$ & $\begin{array}{l}\text { PRISMIV } \\
\text { CRP }\end{array}$ & PIM CRP & $\begin{array}{c}\text { PIM2 } \\
\text { CRP }\end{array}$ & $\begin{array}{l}\text { PIM3 } \\
\text { CRP }\end{array}$ & $\begin{array}{l}\text { PELOD } \\
\text { CRP }\end{array}$ & $\begin{array}{c}\text { PELOD2 } \\
\text { CRP }\end{array}$ \\
\hline PRISM & $\begin{array}{c}0.6 \\
(0.49 \text { to } \\
0.72)\end{array}$ & $\begin{array}{c}-0.13(-0.23 \\
\text { to }-0.03) ; \\
p=0.0122\end{array}$ & $\begin{array}{c}-0.08(-0.18 \\
\text { to } 0.01) \\
\mathrm{p}=0.0857\end{array}$ & $\begin{array}{c}-0.16(- \\
0.27 \text { to }- \\
0.04) \\
\mathrm{p}=0.0059\end{array}$ & $\begin{array}{c}-0.15(- \\
0.27 \text { to }- \\
0.03) \\
\mathrm{p}=0.0125\end{array}$ & $\begin{array}{l}-0.1(-0.23 \\
\text { to } 0.02) \\
\mathrm{p}=0.1023\end{array}$ & $\begin{array}{c}-0.09(- \\
0.19 \text { to } \\
0.02) ; \\
\mathrm{p}=0.1001\end{array}$ & $\begin{array}{c}-0.12(- \\
0.24 \text { to }- \\
0.01) ; \\
\mathrm{p}=0.0359\end{array}$ & $\begin{array}{c}-0.06(- \\
0.13 \text { to } \\
0.01) ; \\
p=0.1166\end{array}$ & $\begin{array}{c}-0.21(-0.3 \\
\text { to }-0.11) \\
p=0\end{array}$ & $\begin{array}{c}-0.19(-0.28 \\
\text { to }-0.11) \\
\mathrm{p}=0\end{array}$ & $\begin{array}{c}-0.17(- \\
0.27 \text { to }- \\
0.06) ; \\
\mathrm{p}=0.0014\end{array}$ & $\begin{array}{c}-0.16(- \\
0.27 \text { to }- \\
0.06) ; \\
\mathrm{p}=0.0026\end{array}$ & $\begin{array}{c}-0.13(- \\
0.24 \text { to }- \\
0.01) \\
\mathrm{p}=0.0356\end{array}$ & $\begin{array}{l}-0.08(-0.2 \\
\text { to } 0.03) \\
\mathrm{p}=0.1665\end{array}$ & $\begin{array}{c}-0.24(-0.33 \\
\text { to }-0.14) \\
p=0\end{array}$ \\
\hline PRISMIII & 0.5 & $\begin{array}{c}0.74(0.65 \\
\text { to } 0.82)\end{array}$ & $\begin{array}{c}0.05(-0.01 \\
\text { to } 0.11) \\
\mathrm{p}=0.1192\end{array}$ & $\begin{array}{c}-0.02(- \\
0.12 \text { to } \\
0.08) \\
\mathrm{p}=0.6285\end{array}$ & $\begin{array}{c}-0.02(- \\
0.12 \text { to } \\
0.09) \\
\mathrm{p}=0.7373\end{array}$ & $\begin{array}{c}0.03(-0.07 \\
\text { to } 0.13) \\
\mathrm{p}=0.603\end{array}$ & $\begin{array}{c}0.05(-0.06 \\
\text { to } 0.15) \\
\mathrm{p}=0.3905\end{array}$ & $\begin{array}{c}0.01(-0.06 \\
\text { to } 0.07) \\
\mathrm{p}=0.8296\end{array}$ & $\begin{array}{c}0.07(-0.04 \\
\text { to } 0.19) \\
p=0.2264\end{array}$ & $\begin{array}{c}-0.07(-0.15 \\
\text { to } 0) ; \\
p=0.0552\end{array}$ & $\begin{array}{c}-0.06(-0.14 \\
\text { to } 0.02) \\
p=0.1175\end{array}$ & $\begin{array}{c}-0.03(- \\
0.15 \text { to } \\
0.08) \\
\mathrm{p}=0.5461\end{array}$ & $\begin{array}{c}-0.03(- \\
0.15 \text { to } \\
0.09) \\
\mathrm{p}=0.5826\end{array}$ & $\begin{array}{c}0.01(-0.11 \\
\text { to } 0.12) ; \\
\mathrm{p}=0.9231\end{array}$ & $\begin{array}{c}0.05(-0.06 \\
\text { to } 0.16) \\
\mathrm{p}=0.3698\end{array}$ & $\begin{array}{c}-0.11(-0.17 \\
\text { to }-0.04) \\
\mathrm{p}=0.0022\end{array}$ \\
\hline PRISMIV & 0.59 & 0.81 & $\begin{array}{c}0.69(0.59 \\
\text { to } 0.79)\end{array}$ & $\begin{array}{c}-0.07(- \\
0.17 \text { to } \\
0.03) ; \\
\mathrm{p}=0.1686\end{array}$ & $\begin{array}{c}-0.06(- \\
0.17 \text { to } \\
0.04) ; \\
\mathrm{p}=0.2317\end{array}$ & $\begin{array}{c}-0.02(- \\
0.13 \text { to } \\
0.09) ; \\
\mathrm{p}=0.7161\end{array}$ & $\begin{array}{c}0(-0.11 \text { to } \\
0.11) ; \\
p=0.9897\end{array}$ & $\begin{array}{c}-0.04(- \\
0.13 \text { to } \\
0.05) ; \\
\mathrm{p}=0.3962\end{array}$ & $\begin{array}{c}0.02(-0.07 \\
\text { to } 0.12) \\
\mathrm{p}=0.6269\end{array}$ & $\begin{array}{c}-0.12(-0.2 \\
\text { to }-0.05) \\
\mathrm{p}=0.0016\end{array}$ & $\begin{array}{c}-0.11(-0.18 \\
\text { to }-0.04) ; \\
p=0.0015\end{array}$ & $\begin{array}{c}-0.08(- \\
0.19 \text { to } \\
0.03) \\
\mathrm{p}=0.1445\end{array}$ & $\begin{array}{c}-0.08(- \\
0.19 \text { to } \\
0.03) ; \\
\mathrm{p}=0.1682\end{array}$ & $\begin{array}{c}-0.04(- \\
0.16 \text { to } \\
0.08) \\
\mathrm{p}=0.4962\end{array}$ & $\begin{array}{c}0 \text { (-0.11 to } \\
0.12) \\
p=0.9675\end{array}$ & $\begin{array}{c}-0.15(-0.23 \\
\text { to }-0.08) \\
\mathrm{p}=1 \mathrm{e}-04\end{array}$ \\
\hline PIM & 0.42 & 0.38 & 0.43 & $\begin{array}{c}0.76(0.67 \\
\text { to } 0.85)\end{array}$ & $\begin{array}{l}0.01(-0.03 \\
\text { to } 0.04) ; \\
p=0.6843\end{array}$ & $\begin{array}{c}0.05(-0.04 \\
\text { to } 0.14) \\
\mathrm{p}=0.2744\end{array}$ & $\begin{array}{c}0.07(-0.03 \\
\text { to } 0.17) \\
\mathrm{p}=0.1564\end{array}$ & $\begin{array}{c}0.03(-0.09 \\
\text { to } 0.15) \\
\mathrm{p}=0.5927\end{array}$ & $\begin{array}{c}0.1(-0.03 \\
\text { to } 0.22) \\
p=0.1214\end{array}$ & $\begin{array}{c}-0.05(-0.14 \\
\text { to } 0.04) ; \\
\mathrm{p}=0.2868\end{array}$ & $\begin{array}{l}-0.04(-0.12 \\
\text { to } 0.05) \\
\mathrm{p}=0.3694\end{array}$ & $\begin{array}{c}-0.01(- \\
0.06 \text { to } \\
0.04) ; \\
p=0.6812\end{array}$ & $\begin{array}{c}-0.01(- \\
0.07 \text { to } \\
0.05) \\
\mathrm{p}=0.7858\end{array}$ & $\begin{array}{c}0.03(-0.07 \\
\text { to } 0.13) \\
\mathrm{p}=0.5613\end{array}$ & $\begin{array}{c}0.07(-0.04 \\
\text { to } 0.18) \\
\mathrm{p}=0.1885\end{array}$ & $\begin{array}{c}-0.08(-0.16 \\
\text { to } 0) ; \\
\mathrm{p}=0.0486\end{array}$ \\
\hline PIM2 & 0.35 & 0.31 & 0.38 & 0.94 & $\begin{array}{c}0.75(0.66 \\
\text { to } 0.85)\end{array}$ & $\begin{array}{c}0.04(-0.04 \\
\text { to } 0.13) ; \\
p=0.3075\end{array}$ & $\begin{array}{c}0.06(-0.04 \\
\text { to } 0.17) \\
p=0.2195\end{array}$ & $\begin{array}{c}0.03(-0.1 \\
\text { to } 0.15) \\
\mathrm{p}=0.6816\end{array}$ & $\mid \begin{array}{c}0.09(-0.04 \\
\text { to } 0.22) \\
p=0.1744\end{array}$ & $\begin{array}{c}-0.06(-0.16 \\
\text { to } 0.04) ; \\
\mathrm{p}=0.2726\end{array}$ & $\begin{array}{c}-0.05(-0.14 \\
\text { to } 0.05) \\
p=0.3321\end{array}$ & $\begin{array}{c}-0.02(- \\
0.07 \text { to } \\
0.04) ; \\
\mathrm{p}=0.5759\end{array}$ & $\begin{array}{c}-0.02(- \\
0.07 \text { to } \\
0.04) ; \\
p=0.596\end{array}$ & $\begin{array}{c}0.02(-0.07 \\
\text { to } 0.12) \\
\mathrm{p}=0.6349\end{array}$ & $\begin{array}{c}0.07(-0.05 \\
\text { to } 0.18) \\
p=0.2475\end{array}$ & $\begin{array}{c}-0.09(-0.18 \\
\text { to } 0) ; \\
\mathrm{p}=0.0528\end{array}$ \\
\hline PIM3 & 0.37 & 0.53 & 0.46 & 0.61 & 0.67 & $\begin{array}{l}0.71(0.6 \\
\text { to } 0.82)\end{array}$ & $\begin{array}{c}0.02(-0.09 \\
\text { to } 0.13) ; \\
\mathrm{p}=0.7227\end{array}$ & $\begin{array}{c}-0.02(- \\
0.13 \text { to } \\
0.09) \\
\mathrm{p}=0.7343\end{array}$ & $\begin{array}{c}0.05(-0.09 \\
\text { to } 0.18) \\
p=0.5086\end{array}$ & $\begin{array}{c}-0.1(-0.21 \\
\text { to } 0.01) \\
\mathrm{p}=0.0837\end{array}$ & $\begin{array}{c}-0.09(-0.2 \\
\text { to } 0.02) \\
\mathrm{p}=0.1243\end{array}$ & $\begin{array}{c}-0.06(- \\
0.16 \text { to } \\
0.03) ; \\
\mathrm{p}=0.2112\end{array}$ & $\begin{array}{c}-0.06(- \\
0.15 \text { to } \\
0.03) \\
\mathrm{p}=0.2039\end{array}$ & $\begin{array}{c}-\mathbf{- 0 . 0 2}(- \\
0.06 \text { to } \\
\mathbf{0 . 0 2}) \\
\mathrm{p}=\mathbf{0 . 3 3 4 9}\end{array}$ & $\begin{array}{c}0.02(-0.09 \\
\text { to } 0.14) \\
\mathrm{p}=0.7018\end{array}$ & $\begin{array}{c}-0.13(-0.23 \\
\text { to }-0.03) \\
\mathrm{p}=0.0077\end{array}$ \\
\hline PELOD & 0.59 & 0.46 & 0.44 & 0.54 & 0.5 & 0.52 & $\begin{array}{c}0.69(0.58 \\
\text { to } 0.8)\end{array}$ & $\begin{array}{c}-0.04(- \\
0.15 \text { to } \\
0.07) ; \\
\mathrm{p}=0.4866\end{array}$ & $\begin{array}{c}0.03(-0.09 \\
\text { to } 0.14) ; \\
p=0.6565\end{array}$ & $\begin{array}{c}-0.12(-0.24 \\
\text { to } 0) \\
\mathrm{p}=0.0478\end{array}$ & $\begin{array}{c}-0.11(-0.22 \\
\quad \text { to } 0) ; \\
\mathrm{p}=0.0547\end{array}$ & $\begin{array}{c}-0.08(- \\
0.19 \text { to } \\
0.03) ; \\
\mathrm{p}=0.1509\end{array}$ & $\begin{array}{c}-0.08(- \\
0.19 \text { to } \\
0.03) \\
\mathrm{p}=0.1636\end{array}$ & $\begin{array}{c}-0.04(- \\
0.16 \text { to } \\
0.08) \\
\mathrm{p}=0.4924\end{array}$ & $\begin{array}{c}0(-0.09 \text { to } \\
0.1) ; \\
p=0.9485\end{array}$ & $\begin{array}{c}-0.15(-0.26 \\
\text { to }-0.05) ; \\
\mathrm{p}=0.0045\end{array}$ \\
\hline PELOD2 & 0.43 & 0.77 & 0.59 & 0.28 & 0.23 & 0.48 & 0.48 & $\begin{array}{c}0.73(0.62 \\
\text { to } 0.83)\end{array}$ & $\mid \begin{array}{c}0.06(-0.05 \\
\text { to } 0.18) ; \\
p=0.2766\end{array}$ & $\begin{array}{c}-0.08(-0.18 \\
\text { to } 0.01) \\
\mathrm{p}=0.0972\end{array}$ & $\begin{array}{c}-0.07(-0.18 \\
\text { to } 0.04) \\
p=0.1924\end{array}$ & $\begin{array}{c}-0.04(- \\
0.17 \text { to } \\
0.09) ; \\
\mathrm{p}=0.5182\end{array}$ & $\begin{array}{c}-0.04(- \\
0.17 \text { to } \\
0.09) \\
\mathrm{p}=0.5433\end{array}$ & $\begin{array}{c}0(-0.12 \text { to } \\
0.12) \\
\mathrm{p}=0.9768\end{array}$ & $\begin{array}{c}0.04(-0.06 \\
\text { to } 0.14) \\
\mathrm{p}=0.4103\end{array}$ & $\begin{array}{c}-0.11(-0.2 \\
\text { to }-0.03) \\
p=0.0082\end{array}$ \\
\hline $\begin{array}{l}\text { PRISM } \\
\text { CRP }\end{array}$ & 0.81 & 0.45 & 0.63 & 0.4 & 0.31 & 0.37 & 0.56 & 0.5 & $\begin{array}{c}0.66(0.54 \\
\text { to } 0.79)\end{array}$ & $\begin{array}{c}-0.15(-0.24 \\
\text { to }-0.05) \\
\mathrm{p}=0.0032\end{array}$ & $\begin{array}{c}-0.13(-0.23 \\
\text { to }-0.03) \\
p=0.0084\end{array}$ & $\begin{array}{c}-0.11(- \\
0.22 \text { to } \\
0.01) ; \\
\mathrm{p}=0.0685\end{array}$ & $\begin{array}{c}-0.1(-0.22 \\
\text { to } 0.01) \\
\mathrm{p}=0.0694\end{array}$ & $\begin{array}{c}-0.07(- \\
0.19 \text { to } \\
0.06) \\
\mathrm{p}=0.2944\end{array}$ & $\begin{array}{c}-0.02(- \\
0.11 \text { to } \\
0.07) ; \\
\mathrm{p}=0.6389\end{array}$ & $\begin{array}{c}-0.18(-0.27 \\
\text { to }-0.08) \\
\mathrm{p}=3 \mathrm{e}-04\end{array}$ \\
\hline
\end{tabular}




\begin{tabular}{|c|c|c|c|c|c|c|c|c|c|c|c|c|c|c|c|c|}
\hline \multirow[b]{3}{*}{$\begin{array}{l}\text { PRISMIII } \\
\text { CRP }\end{array}$} & \multicolumn{8}{|c|}{$\mathrm{p}=0.211$} & \multicolumn{8}{|c|}{$p=0.2778$} \\
\hline & PRISM & PRISMIII & PRISMIV & PIM & PIM2 & PIM3 & PELOD & PELOD2 & $\begin{array}{c}\text { PRISM } \\
\text { CRP }\end{array}$ & $\begin{array}{c}\text { PRISMIII } \\
\text { CRP }\end{array}$ & $\begin{array}{c}\text { PRISMIV } \\
\text { CRP }\end{array}$ & PIM CRP & $\begin{array}{l}\text { PIM2 } \\
\text { CRP }\end{array}$ & $\begin{array}{l}\text { PIM3 } \\
\text { CRP }\end{array}$ & $\begin{array}{l}\text { PELOD } \\
\text { CRP }\end{array}$ & $\begin{array}{c}\text { PELOD2 } \\
\text { CRP }\end{array}$ \\
\hline & 0.52 & 0.61 & 0.67 & 0.47 & 0.35 & 0.36 & 0.28 & 0.49 & 0.63 & $\begin{array}{c}0.81(0.73 \\
\text { to } 0.89)\end{array}$ & $\begin{array}{c}0.01(-0.03 \\
\text { to } 0.06) ; \\
p=0.6393\end{array}$ & $\begin{array}{l}0.04(-0.05 \\
\text { to } 0.13) \\
p=0.3877\end{array}$ & $\begin{array}{l}0.04(-0.05 \\
\text { to } 0.13) \\
p=0.3847\end{array}$ & $\begin{array}{c}0.08(-0.03 \\
\text { to } 0.19) \\
p=0.1557\end{array}$ & $\begin{array}{l}0.12(0.02 \\
\text { to } 0.23) \\
p=0.0202\end{array}$ & $\begin{array}{c}-0.03(-0.07 \\
\text { to } 0.01) \\
\mathrm{p}=0.1187\end{array}$ \\
\hline $\begin{array}{l}\text { PRISMIV } \\
\text { CRP }\end{array}$ & 0.65 & 0.57 & 0.73 & 0.54 & 0.45 & 0.34 & 0.36 & 0.37 & 0.6 & 0.85 & $\begin{array}{c}0.8(0.72 \text { to } \\
0.88)\end{array}$ & $\begin{array}{l}0.03(-0.05 \\
\text { to } 0.11) \\
p=0.4858\end{array}$ & $\begin{array}{l}0.03(-0.06 \\
\text { to } 0.12) \\
\mathrm{p}=0.502\end{array}$ & $\begin{array}{c}0.07(-0.04 \\
\text { to } 0.18) ; \\
p=0.2262\end{array}$ & $\begin{array}{c}0.11(0 \text { to } \\
0.22) ; \\
p=0.0476\end{array}$ & $\begin{array}{c}-0.04(-0.1 \\
\text { to } 0.01) \\
\mathrm{p}=0.1203\end{array}$ \\
\hline PIM CRP & 0.53 & 0.27 & 0.37 & 0.88 & 0.81 & 0.59 & 0.44 & 0.19 & 0.49 & 0.52 & 0.61 & $\begin{array}{c}0.77(0.67 \\
\text { to } 0.87)\end{array}$ & $\begin{array}{c}0(-0.04 \text { to } \\
0.04) ; \\
p=0.9526\end{array}$ & $\begin{array}{l}0.04(-0.05 \\
\text { to } 0.13) \\
p=0.3739\end{array}$ & $\begin{array}{c}0.08(-0.03 \\
\text { to } 0.2) \\
\mathrm{p}=0.1457\end{array}$ & $\begin{array}{c}-0.07(-0.15 \\
\text { to } 0.01) \\
p=0.0794\end{array}$ \\
\hline $\begin{array}{l}\text { PIM2 } \\
\text { CRP }\end{array}$ & 0.49 & 0.19 & 0.33 & 0.79 & 0.82 & 0.62 & 0.43 & 0.15 & 0.5 & 0.5 & 0.54 & 0.9 & $\begin{array}{c}0.77(0.67 \\
\text { to } 0.87)\end{array}$ & $\begin{array}{l}0.04(-0.04 \\
\text { to } 0.12) \\
p=0.3386\end{array}$ & $\begin{array}{c}0.08(-0.03 \\
\text { to } 0.19) ; \\
p=0.1468\end{array}$ & $\begin{array}{c}-0.07(-0.16 \\
\text { to } 0.01) \\
\mathrm{p}=0.0975\end{array}$ \\
\hline $\begin{array}{l}\text { PIM3 } \\
\text { CRP }\end{array}$ & 0.47 & 0.43 & 0.39 & 0.54 & 0.58 & 0.93 & 0.48 & 0.39 & 0.48 & 0.43 & 0.41 & 0.67 & 0.74 & $\begin{array}{l}0.73(0.61 \\
\text { to } 0.85)\end{array}$ & $\begin{array}{c}0.04(-0.07 \\
\text { to } 0.16) ; \\
\mathrm{p}=0.449\end{array}$ & $\begin{array}{c}-0.11(-0.21 \\
\text { to }-0.02) ; \\
\mathrm{p}=0.0216\end{array}$ \\
\hline $\begin{array}{l}\text { PELOD } \\
\text { CRP }\end{array}$ & 0.45 & 0.42 & 0.4 & 0.4 & 0.36 & 0.44 & 0.63 & 0.56 & 0.69 & 0.44 & 0.35 & 0.4 & 0.42 & 0.49 & $\begin{array}{l}0.69(0.58 \\
\text { to } 0.79)\end{array}$ & $\begin{array}{c}-0.15(-0.24 \\
\text { to }-0.07) \\
p=4 e-04\end{array}$ \\
\hline $\begin{array}{l}\text { PELOD2 } \\
\text { CRP }\end{array}$ & 0.53 & 0.66 & 0.64 & 0.53 & 0.42 & 0.51 & 0.4 & 0.59 & 0.64 & 0.88 & 0.76 & 0.59 & 0.52 & 0.58 & 0.62 & $\begin{array}{c}0.84(0.77 \\
\text { to } 0.91)\end{array}$ \\
\hline
\end{tabular}

a Completed data: 246 patients; AUC with CI for each score on diagonal, correlation between scores below diagonal, difference in AUC with CI and p value above diagonal 